YEARBOOK

of ANTITRUST

and REGULATORY

STUDIES

www.yars.wz.uw.edu.pl
Peer-reviewed scientific periodical, focusing on legal and economic issues of antitrust and regulation. Creative Commons Attribution-No Derivative Works 3.0 Poland License.

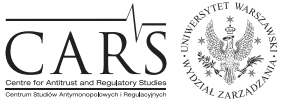

Centre for Antitrust and Regulatory Studies, University of Warsaw, Faculty of Management www.cars.wZ.uw.edu.pl

\title{
The European Competition Network in the European Administrative System: Theoretical Concerns
}

\author{
by \\ Erzsébet Csatlós*
}

\section{CONTENTS}

I. The nature of the European administrative system

II. Placing the European Competition Network in the European administrative organisation

III. Cooperation within the European administrative organisation

IV. Networks of European administration and the role of the ECN among them

V. Legal aspects of network structures

VI. The European Competition Network in view of legal challenges concerning networks

VII. Future path of development

VIII. Concluding remarks

\section{Abstract}

The public administration of the European Union (EU) is a sui generis multi-level structure under constant development. After five decades of successful functioning, the European Union still lacks a coherent and comprehensive set of codified rules of administrative procedure at all levels. The existing acquis related to European administration and administrative procedures is fragmented, sector specific and although it is based on the constitutional principles of the democratic traditions of its Member States, such coincidence is often insufficient for the present requirements

* Senior lecturer, Department of Public Administrative Law, Faculty of Law and Political Science, University of Szeged; csatlos.e@juris.u-szeged.hu. An earlier version of this contribution was presented at the First Gaetano Filangieri Conference on Freedom of Commerce 'Recent developments in EU Competition Law', held at the University of Naples 'Federico II' on 8-9 May 2018. Article received: 16 April 2018; accepted: 20 June 2018. 
of good administration. The EU basically relies on indirect administration, while a growing number of cooperation forms exists of the competent authorities that aims to ensure efficacy of execution and to overcome diversity of non-harmonised legal areas. The aim of this paper is to place the European Competition Network $(\mathrm{ECN})$ in this structure, explore and examine its legal nature as it is probably the most advanced example for such cooperation.

The ECN incorporates and reveals the major procedural law questions of European administration; it is a rather successful form of cooperation, and although its core issues fail to correspond to the fundamental requirements of European administrative procedures, there seem to be positive changes in the evaluation of soft law and the functioning of the system.

\section{Résumé}

L'administration publique de l'Union européenne (UE) est une structure sui generis aux plusieurs niveaux de l'évolution constante. Après cinq décennies de bon fonctionnement, l'Union européenne (UE) ne dispose toujours pas de l'ensemble cohérent et complexe de règles codifiées de procédures administratives à tous les niveaux. Lacquis existant relatif à l'administration européenne et aux procédures administratives est fragmenté et spécifique au secteur. Même si l'acquis est fondé sur les principes constitutionnels des traditions démocratiques des États membres, une telle coïncidence est souvent insuffisante par rapport aux exigences actuelles d'une bonne administration. L'UE s'appuie essentiellement sur l'administration indirecte alors qu'il existe un nombre croissant de type de coopération entre les autorités compétents afin d'assurer l'efficacité de l'exécution et de surmonter la diversité entre des domaines du droit non-harmonisés. L'objectif de cet article est de placer le Réseau européen de la concurrence (ECN) dans cette structure, d'explorer et d'examiner sa nature juridique, car il s'agit probablement de l'exemple le plus avancé de ce type de coopération. Le REC intègre et révèle les principales questions de droit procédural de l'administration européenne. Il est une forme de coopération plutôt fructueuse, et bien que ses enjeux essentiels ne correspondent pas aux exigences fondamentales des procédures administratives européennes, il semble y avoir des changements positifs dans l'évaluation du soft law et du fonctionnement du système.

Key words: European administration; cooperation; public authority; ECN; soft law.

JEL: K1

\section{The nature of the European administrative system}

After five decades of successful functioning, the European Union still lacks a coherent and comprehensive set of codified rules of administrative 
procedures at all levels (Schwarze, 2011, p. 7). The existing acquis related to European administration and administrative procedures is fragmented, sector specific and although it is based on constitutional principles of the democratic traditions of its Member States, the reciprocal influence between national law and European administrative achievements is a well-known and widely accepted phenomenon. However, the EU basically relies on indirect administration while, at the same time, the number of network structures that connects direct and indirect administration of the multi-level European administrative space is increasing.

The EU's own executive capacity (direct administration) is relatively small (Chiti, 2011, p. 21). ${ }^{1}$ The execution is therefore left to the administrative capacity of Member States (indirect administration) (Ficzere, 2011, pp. 383-84). The correlation of the different levels makes it possible to describe the EU as a multi-level administrative system known as the European administrative space (EAS) (Dezső-Vincze, 2012, p. 490; Heidbreder, 2009, p. 5; Torma, 2011, p. 197; Koprić, Musa and Novak, 2011, pp. 1545-1546; Curtin and Egeberg, 2013, pp. 30-32). The concept of the EAS comes from the intergovernmental history of the integration, when administration was a sphere for domestic affairs and only uniform implementation was under the supervision of EU level institutions. Meanwhile, the key for successful execution of the acquis has always been properly functioning public administration, which is based on the common constitutional principles of democratic Member States (Drechsler, 2009, p. 7, 10). ${ }^{2}$ Moreover, the direct level of EU administration shall also be based on them; ${ }^{3}$ however, the reciprocal influence between

\footnotetext{
1 As the guardian of the Treaties, the European Commission is responsible for the proper execution of EU law; in fact, each Commissioner is responsible for specific policy areas to defend the interests of the EU while they are in charge with drafting and monitoring proper execution by the Member States. The Commission is entitled to establish agencies with a technical, scientific, or administrative function to help EU institutions in policy formation, law-making and execution. Consolidated version of the Treaty on the Functioning of the European Union (hereinafter, TFEU). OJ C 326, 26.10.2012. pp. 47-390. Article 352. Sometimes they are called decentralized agencies as their seats are in different Member States although they are considered central supra-national organs, rather than local ones placed on the territory of all the Member States. European Agencies - The Way forward. Brussels, Communication from the Commission to the European Parliament and the Council, 11.3.2008, $\operatorname{COM(2008)~} 135$ final, p. 4.

2 The Lisbon Special European Council (March 2000): Towards a Europe of Innovation and Knowledge. Presidency Conclusions Lisbon European Council 23 and 24 March 2000. point 9. and 17. http://eur-lex.europa.eu/legal-content/EN/TXT/?uri=uriserv:c10241 (10.03.2018).

3 As Klucka highlighted, the European Court of Justice had already indicated in 1963 that Community administration must follow rules related to the requirements of sound justice and good administration. Since then, the ECJ has developed an extensive set of administrative law principles that have been, to a large extent, derived from the administrative provisions of the
} 
national law and European administrative law is a well-known and widely accepted phenomenon of today (Klucka, 2007, p. 1048).

The principle of autonomy of the EU along with the principle of sovereignty of its Member States form the axis that basically dominates the functioning and organisation of the execution of EU policies. The powers transferred from Member States enable the EU institutions to legislate. In certain policies, the EU has exclusive competences, ${ }^{4}$ while in others the competences are shared between the EU and the Member States and the latter can act only if the EU has chosen not to. ${ }^{5}$ The EU has the weakest powers when it has competence to support, coordinate or supplement the actions of the Member States. ${ }^{6}$ There is no general competence in the entire policy area but only with regard to matters specified by TEU-TFEU provisions. ${ }^{7}$ However, the executive organisation is not expressis verbis regulated by EU legal acts: Member States are required to have administrative systems and public administration institutions capable of transposing, implementing and enforcing the acquis according to the principle of 'obligatory results' (obligation de résultat).$^{8}$

However, over the last decades, the European Union has developed a series of $a d$ hoc administrative procedures for the direct implementation of its rules in a number of areas, such as competition policy, trade policy, state aids, access to EU documents, or the EU civil service, which resulted in a fragmented body of rules which do not share common normative background (Panizza, 2015, p. 1). It was only the Lisbon Treaty that introduced a legislative competence for administrative cooperation, which is now described in Article 197 TFEU, although there have been an increasing number of policies, in fact, that requires intensive cooperation and intermediate networking of competent authorities at national and supra-national level. The nature and depth of such co-work depends on the level of the Europeanisation of a given policy. The various forms of trans-national interaction define the concept of composite administration, which is often performed in a networking structure of the competent authorities. The existence of such a relationship between the executive apparatus requires a re-think of the concept on a simple European administrative space moving it closer towards a multilevel European

Member States; C-32/26 Maurice Alvis v. Council, ECLI:EU:C:1963:15, p. 55; Klucka, 2007, p. 1048.

4 Article 3 TFEU.

5 Article 4 TFEU.

6 Article 6 TFEU.

7 See Treaty on the European Union - Treaty on the Functioning of the European Union. List of decision-making procedures by article (updated 17.12.2009) http://ec.europa.eu/ codecision/docs/legal_bases_en.pdf (10.03.2018).

${ }^{8}$ European Principles for Public Administration, SIGMA Papers: No. 27, CCNM/SIGMA/ PUMA(99)44/REV1, 1999 (hereinafter, SIGMA 27), p. 6. 
administrative organisation (Hofmann, 2009b, p. 45) where the cooperation of authorities is, therefore, a significant feature.

\section{Placing the European Competition Network in the European administrative organisation}

The EU basically relies on indirect administration and the number of policies which require the systematic cooperation of competent authorities at the direct and indirect level is increasing. The European Competition Network (ECN) is probably the most advanced example of this form of cooperation due to several specificities to be presented below.

The establishing of competition rules necessary for the functioning of the internal market is an exclusive competence of the European Union (Article 3(1)(b) TFEU). In the European administrative system, competition policy is executed by the Commission (DG COMP) and the national competition authorities of the Member States (NCAs) forming together a network of public authorities applying the EU competition rules in close cooperation. ${ }^{9}$ Within the ECN, the Commission serves as a strong central authority with a significant degree of control, ${ }^{10}$ but NCAs are the primary enforcers of competition rules. The ECN is the forum for discussion of competition policy issues and particular cases between NCAs and the Commission as well as to exchange information and re-allocate cases by preventing parallel enforcement by multiple authorities, since either the Commission or any NCA can investigate an alleged breach of EU competition rules. ${ }^{11}$

${ }^{9}$ Council Regulation (EC) No 1/2003 of 16 December 2002 on the implementation of the rules on competition laid down in Articles 81 and 82 of the Treaty (Text with EEA relevance), OJ L 1, 4.01.2003 (hereinafter, Regulation 1/2003), (15).

10 In a formal perspective, for example, NCAs do not have the same rights as the Commission to obtain information, evidence or administrative assistance from other ECN members (Brammer, 2008, p. 352) It needs also to be noted that there are no previously settled rules on the division of jurisdiction or policy competences, and the Commission has extended influence on it (Mataija, 2010, pp. 76-77).

11 Commission Notice on cooperation within the Network of Competition Authorities (Text with EEA relevance), OJ C 101, 27.04.2004, pp. 43-53 (hereinafter, Network Notice), points 5, 13. The system is based on parallel competences in which all competition authorities have the power to apply Article 101 and 102 TFEU and are responsible for an efficient division of work. Each national authority enjoys full discretion in deciding whether or not to investigate a case, or to designate one of them as a lead authority and to delegate tasks to the lead authority such as, for example, the coordination of investigative measures, while each authority remains responsible for conducting its own proceedings. 
Here lies the unique administrative law feature of competition matters: the supra-national level of administration (DG COMP) is entitled to act with authority power, that is, it can formulate legal situations and impose obligations or give rights by unilateral decisions in individual cases. It is rare, as the enforcement of EU law is basically in the hands of the authorities of the Member States, and the aim of the EU has never been either the duplication of an executive system, or the substitution of this task of Member States' administration. The fact that authority power is placed on both levels of European administration gives specificity to this cooperation, while its other aspects are typical and natural features of composite administrative procedures.

\section{Cooperation within the European administrative organisation}

Cooperation is the process of entering into a relationship with another institution or organ to achieve a system derived goal. Under its classical meaning, mutual assistance stands for a supplementary activity to a procedure of another authority upon a prior request, which can be rejected for various reasons even if the request is based on a valid agreement by the parties. Networks ${ }^{12}$ in the EU are established to ensure a constant channel for systematic cooperation and data flow where these activities shall be done in an automatic way, without the possibility of rejecting collaboration or retaining information. Therefore, within the context of European administration, in many policy areas the development of the integration of EU and national administrative proceedings has led to 'administrative procedures which - although finally terminated by a decision at either European or national level - are undertaken with input from various jurisdictions' (Hofmann, 2015, p. 304).

However, the legal nature of the establishing document as well as applicable procedural rules vary from network to network. Mastenbroek and Martinsen highlighted that academic literature uses the term 'network' with different attributives to describe a sort of systematic teamwork. Moreover, in the EU, the form of collaboration may also take various forms: both in the vertical

12 Networks often appear in international relations under different titles. International institutions and trans-national networks involving both governmental and non-governmental actors to pool expertise and to produce a suitable solution for common challenges. They often lack governmental powers and de iure empowerment while they contribute to the creation of de facto obligations. The obligatory nature of the soft law they create has roots in the economic or political inter-dependence of States, while the legitimacy and administrative control is missing from this system. So, domestic public administrative law, as, in fact, most elements of public law, seems to be put aside while foreign elements infiltrates domestic public administration (Bianchi, 2016, p. 61; Kinsbury, Kirsch, Stewart and Wiener, 2005, p. 3). 
relation between the European Commission and agencies on one hand and the Member States' agencies on the other, as well as the 'horizontal' cooperation directly between different national agencies' (Hofmann and Türk, 2006, p. 90). They share the same feature of having no uniform normative background and are the result of the development of integration.

Based on the categorisation of Hofmann and Türk, administrative authority networks basically appear at two phases of the European administrative system: in the preparation for the conditions of implementation of EU policies and in the decision-making process in individual cases. Planning networks are based on the pooling of expertise, like in comitology procedures. In the executive phase, different networks are identified ranging from the simplest form of information networks (which are established to channel and to co-ordinate the generation and editing of data relevant to administrative activity), to trans-territorial networks, which are the channels for administrative acts by administrations which have effect outside of their own jurisdiction due to the obligation of their mutual recognition (Hofmann and Türk, 2006, pp. 90-91). The most commonly used network of composite administration includes individually binding decisions made on the Member State or European level. The number and relevance of such enforcement networks has increased in recent years with both vertical and horizontal relations, and its most publicised example is the enforcement regime for EU competition law under Articles 101 and 102 TFEU. (Hofmann, 2009a, pp. 201-202). Enforcement networks establish a channel for cooperation with the aim of producing one single decision of one of them, so it is like a systematic discussion and mutual assistance forum, if this latter is needed. Enforcement ensures effectiveness involving the exercise of public power with the objective of preventing or responding to a violation of the issued norm via an enforcement mechanism (Roben, 2008, pp. 1965-1967). Although in competition matters the Commission is entitled to proceed and has authority power, it is very rare that a supra-national organ disposes of public authority so far as to be able to produce binding individual acts in a procedure. It is also rare within the EU that regulatory networks (Kingsbury, Krisch and Stewart, 2005, pp. 16-17) are formed even if practical concerns support self-regulation, which tends to compensate for the insufficiencies of legal acts with soft law norms, which they issue for the sake of a uniform application of the law.

Relying on Bogdandy's concept, authority means the legal capacity to determine the situation of others and to reduce their freedom, i.e. to unilaterally shape their legal or factual situation without their consent. It may be manifested in individual acts and in a broader sense; it can also mean the capacity to produce such effect through a non-binding act which only conditions another legal subject. Non-binding standards are often a manifestation of this kind of exercise of public authority and they 'are followed, inter alia, because the 
benefits of observing them outweighs the disadvantages of ignoring or because they are equipped with implementing mechanisms imposing positive and negative sanction' (Bogdandy, 2017, pp. 11-12). Under that concept, regulatory networks seem to be an advanced form of enforcement networks taking into account that the regulatory network supposes the existence of public authority.

At present, no general piece of legislation exists which provides a clear procedure for cross-border or multi-level mutual assistance (Galetta, Hofmann, Schneider and Tünsmeyer, 2014, p. 203). Often, the normative background for network cooperation also lies in soft law. However, soft law has pitfalls not only in terms of material law but also concerning procedural law aspects as it weakens legitimacy, effectiveness, and transparency of actions within (Smyrnova, 2013, p. 125). At the same time, the existence and proper functioning of a procedural framework is a precondition for the effective implementation of EU law (Kristjánsdóttir, 2013, p. 238). Meanwhile, effectiveness shall not dominate over legitimacy; legality of acts shall result in effectiveness. ${ }^{13}$

\section{Networks of European administration and the role of ECN among them}

Networks generally emerge naturally between actors due to their interdependence towards a common goal. Meanwhile, legislation has not yet followed the development of networking structures. Concrete executive instructions to help uniform legal practice at Member States' level often appear in non-legislative acts of the Commission. They may take the form of delegated acts (Hardacre and Kaeding, 2011, pp. 16-19; Türk, 2012, pp. 77-78), ${ }^{14}$ implementing acts ${ }^{15}$ and sometimes in different kinds of soft law

13 Although both legitimacy and effectiveness are important principles of public administration, they presuppose different perspectives: legitimacy is a legal one, while effectiveness is a management concept (Metcalfe, 2001, p. 6); ReNEUAL Book VI-3 (15) (Galetta, Hofmann, Lottini, Marsch, Schneider and Tidghi, 2014, p. 271).

14 Article 290 TFEU allows the EU legislator to delegate to the Commission the power to adopt non-legislative acts of general application that supplement or amend certain non-essential elements of a legislative act. Delegated acts may add new but non-essential rules or involve a subsequent amendment to certain, often highly technical, aspects of a legislative act. The delegation of power to adopt delegated acts is nevertheless subject to strict limits; the objectives, content, scope, and duration of the delegation of power must be defined in the legislative acts. The power can be withdrawn anytime.

15 It is primarily the duty of Member States to implement legally binding EU acts unless such acts require uniform conditions for their implementation. In these cases, based on the authorization of Article 291 TFEU, the Commission or, in duly justified specific cases and in cases provided in the Articles 24 and 26 TEU, the Council is empowered to adopt implementing 
documents of agencies (Chiti, 2015, pp. 315-316) ${ }^{16}$ and other bodies. It can also happen that the document in question remains quiet on the legal nature of such kind of provisions. ${ }^{17}$ Beside implementation orders in the different kinds of norms, the cooperation between the executors is a necessary basis for the uniform implementation and execution of EU law. Different sort of networks of competent organs of both levels of European administration are formed 'to fill the gap between the EU's policy ambitions and its limited administrative capacities' (Mastenbroek and Sindbjerg, 2018, pp. 423-424). ${ }^{18}$ In stricto sensu, all administrative cooperation forms are manifestations of mutual assistance between the actors, however, the classical meaning of this expression shall be distinguished from network cooperation. ${ }^{19}$

Networks generally emerge naturally between actors due to their interdependence towards a common goal. Although there are argumentations that a non-formal version of the ECN existed even under the regime of Regulation 17/62 (Cengiz, 2010, pp. 663, 665), formally, the ECN was established later. The normative background to regulate the basic features of the relationship among NCAs, and between NCAs and the European Commission is found in Chapter IV of Regulation 1/2003, and the Commission's Network Notice of 200420 (Mataija, 2010, p. 79; Cengiz, 2010, p. 664; de Visser, 2009, p. 217).

acts. See p. ex. RAPEX Guidelines Directive. Commission Decision of 16 December 2009 laying down guidelines for the management of the Community Rapid Information System 'RAPEX' established under Article 12 and of the notification procedure established under Article 11 of Directive 2001/95/EC (the General Product Safety Directive), OJ L 22, 26.01.2010, pp. 1-64.

16 Agencies may have regulative power but only in a few cases and not in a general manner (Meroni doctrine). 9/56, Meroni v. Haute autorité ECLI:EU:C:1958:7. p. 152. In case of crossborder healthcare, guidance can be adopted for the implementation of the directive but it does not give further details on its possible legal force; Cross-Border Healthcare Directive; Directive 2011/24/EU of the European Parliament and of the Council of 9 March 2011 on the application of patients' rights in cross-border healthcare, OJ L 88, 4.04.2011, pp. 45-65, Article 11(2)(b).

17 See p. ex. Directive 2010/63/EU of the European Parliament and of the Council of 22 September 2010 on the protection of animals used for scientific purposes, OJ L 276, 20.10.2010, pp. 33-79; Article 23(4) of Directive 2010/40/EU of the European Parliament and of the Council of 7 July 2010 on the framework for the deployment of Intelligent Transport Systems in the field of road transport and for interfaces with other modes of transport, OJ L 207, 6.08.2010, pp. 1-13, Article 9.

18 However, they can also be executive in nature, literature primarily focuses on regulatory networks and several terms are used to cover more or less the same phenomenon: networks, trans-national regulatory networks; trans-national administrative networks; trans-national networks; administrative networks; and trans-governmental networks. Cf. Slaughter, 2003, pp. 1041-1075.

19 Cf. ReNEUAL Book V (Galetta, Hofmann, Schneider, and Tünsmeyer, 2014) and VI (Galetta, Hofmann, Lottini, Marsch, Schneider, and Tidghi, 2014).

${ }^{20}$ Regulation 1/2003, (15)-(18); Network Notice. 
EU competition policy requires uniform execution. Therefore, there are different sets of enforcement methods and tools at the disposal of Member State authorities, as well as different sets of guarantees (Israel, Lang and Hübener, 2010, p. 23). To eliminate differences, the ECN's competition authorities express their common views in the form of 'recommendations on several topics in particular key investigative and decision-making powers, which are intended as "advocacy tools vis-à-vis policy makers"'. ${ }^{21}$ Meanwhile, even if the aim of the cooperation mechanism of the ECN is intended to ensure coherent application of EU competition rules in the Member State, ${ }^{22}$ the ECN itself is not empowered to adopt legally binding rules. ${ }^{23}$ The Commission may adopt notices and guidelines as flexible tools are useful for explaining and announcing Commission policy, and for explaining its interpretation of the competition rules, even if these are not legal acts. ${ }^{24}$

\section{Legal regulation of network structures}

Network structures are an essential administrative phenomenon in executing EU acquis; they establish a stable and constant channel of authorities; they are the catalysts of composite administration and a multi-level administrative system.

However, very few policy-specific legal provisions exist in EU law to regulate in detail the procedural phases of composite administration and the number of common rules is even fewer. Networks began as informal regimes, but have developed into recognizable forms of international administration over the last decades (Zaring, 2005, p. 548). So far, legislation have not yet followed the development of the networks, thus there is no general normative background in a form of a legal act to cover all phases of the process of a composite administrative procedure. Usually, a legal act on the policy calls for the cooperation mechanism, and the details and rules that govern the activity of the actors and their collaboration varies from policy to policy, and often take the form of soft law under different sorts of title: notes, guidance,

21 See: Documents: Investigative and decision-making powers. http://ec.europa.eu/ competition/ecn/documents.html (10.03.2018).

22 428/14 DHL Express and DHL Global Forwarding, ECLI:EU:C:2016:27 (hereinafter, DHL case), para. 30; 429/07 Inspecteur van de Belastingdienst v X BV., EU:C:2009:359, para. 20; C-375/09 Prezes Urzędu Ochrony Konkurencji i Konsumentów v Tele2 Polska sp. z o.o., devenue Netia SA., EU:C:2011:270, para. 26.

${ }^{23}$ DHL case 32, 35.

${ }^{24}$ Network Notice, point 64. 
guideline, instruction, etc. (Galetta, Hofmann, Puigpelat and Ziller, 2015, pp. 6,8) Their distinctive nature is also indicated by the way in which they are published, if they are published in the Official Journal of the EU. ${ }^{25}$

Soft law has roots and two meanings in international law: (a) an informal regulation of behaviour that is not a source of international law, although it is followed as such; or it is (b) acknowledged as a source of international law but without normative content: it cannot be the source of neither rights nor obligations. As the successful application of EU law requires the enforceability by authorities and judicial organs, ${ }^{26}$ this latter meaning shall dominate in legal practice (Kovács, Tóth and Forgács, 2016, pp. 2-3).

Due to its nature, there is a general objection against using soft law as it is 'based on common practice, is ambiguous and pernicious and should not be used $^{27}$ (Fegus, 2014, p. 146.) Critical comments on the sue of soft law name democratic deficit and transparency concerns, as soft law is produced outside the frameworks of the commonly accepted decision-making system (Vogiatzis, 2018, p. 225; Cengiz, 2010, p. 673). Moreover, soft law is outside the scope of classical judicial review and does not provide full judicial protection. ${ }^{28}$ At the same time, these documents are significant sources of interpretation, and so they are relevant normative provisions to achieve the proper execution of EU norms with helping administrative cooperation. They are important fillers of legal gaps, although they can never substitute formal legislation and legal acts. ${ }^{29}$ Networks with a regulatory nature incorporate, therefore, challenges to the legal order when they aim to synthesize legal practice by way of sharing best practice or interpreting Treaty-based provisions.

25 Even if it contains significant information, the Notice on Cooperation and the Leniency Notice adopted by the ECN was published in the 'C' series of the Official Journal of the European Union, which, by contrast with its ' $\mathrm{L}$ ' series, is not intended for the publication of legally binding measures, but only of information, recommendations and opinions concerning the European Union. See: C-410/09 Polska Telefonia Cyfrowa sp. z o.o. v Prezes Urzędu Komunikacji Elektronicznej, EU:C: 2011:294, para. 35; C-226/11 Expedia Inc. v Autorité de la concurrence and Others, EU:C:2012:795, para. 30. Cf. Opinion of AG Kokott of 6 September 2012 in Expedia, C-226/11, ECLI:EU:C:2012:544, para. 37; Practitioner's view, p. 20.

26 Cf. Article 263 TFEU excluding recommendations and opinions, ie non-binding legal acts under Article 288 from the scope of the CJEU's competences (Kovács, Tóth and Forgács, 2016, pp. 2-3).

27 European Parliament resolution of 4 September 2007 on institutional and legal implications of the use of 'soft law' instruments (2007/2028(INI)) (hereinafter, EP Soft Law Resolution), A.

28 EP Soft Law Resolution, A, D, E, 2-4.

29 See C-57/95 French Republic $v$ Commission of the European Communities, ECLI:EU:C:1997:164, para. 23. If a communication of the Commission is binding or aims to create an obligation on third parties that did not existing in EU hard law, it should be the subject of an annulment procedure (Kovács, Tóth and Forgács, 2016, p. 6). 
In the last two decades, the number of soft law documents in the EU has been increasing and the Court of Justice of the EU (CJEU) practice is 'not merely acknowledging the existence of EU soft acts but is also prepared to take these acts into account when deriving its decisions' (Fegus, 2014, p. 150; see also: Ştefan, 2013, p. 197). ${ }^{30}$ Originally, '[e]ach institution shall act within the limits of the powers conferred upon it by these Treaties and in conformity with the procedures, conditions and objectives set out in them'31 (Senden, 2005, p. 84) thus soft law has, in fact, been used historically to mitigate the lack of formal law-making capacity and/or means of enforcement. ${ }^{32}$ Where the EU has competence to legislate, this precludes the use of ' $[r]$ ules of conduct that are laid down in instruments which have not been attributed legally binding force as such'. Nevertheless, in certain cases they may produce legal and practical effects as they are usually produced to that end, ${ }^{33}$ although there is a clear division between their legal effects and legally binding force in practice, meaning that they are accepted to confer rights and obligations only under very exceptional circumstances ${ }^{34}$ (Ştefan, 2013, pp. 197-200). Therefore, according to Kovács, Tóth and Forgács, the legal effect of soft law could be described as a vertical indirect effect, 'the same as is attributable to directly effective rules in an unimplemented directive'; that third parties can rely on soft law rules against EU authorities, but not in horizontal disputes against private parties (Kovács, Tóth and Forgács, 2015, pp. 5-6). Besides substantive law, soft law has become a crucial point in the era of individual rights and fundamental requirements vis-à-vis public administrative procedures applying EU law (Klucka, 2007, p. 1047). If a procedure that includes sharing of information, including personal and business data (Muheme, Neyrinck and Petit, 2016, pp. 152-153), ${ }^{35}$ followed by case allocation and the final decision-making forum, but the procedural phase to that end is based on uncertain, unpredictable advisory provisions of soft law,

${ }^{30}$ Even in the field of foreign relations, soft law has been gaining significance. See C-399/12 Federal Republic of Germany v Council of the European Union, ECLI:EU:C:2014:2258, para. 50; C-45/07 Commission v Greece, EU:C:2009:81, para. 30 and 31; Opinion 2/91, Opinion delivered pursuant to the second subparagraph of Article 228 (1) of the EEC Treaty, ECR 1993 I-01061106, para. 5. See also: Ortino, 2017, p. 925-926.

31 Consolidated version of the Treaty on the Functioning of the European Union (hereinafter, TEU), OJ C 326, 26.10.2012, pp. 47-390, Article 13(2).

32 EP Soft Law Resolution, K.

33 EP Soft Law Resolution, L.

${ }^{34}$ Even though soft law might not introduce new legal obligations, it might promote a very radical interpretation of an obligation provided in hard law; this is how it leads to significant effects on the legal situation of individuals or Member States. In fact, without soft law guidance on interpretation, national or European authorities might interpret a specific hard law obligation in a diverse way; Ştefan, 2013, p. 182.

35 See the importance of personal data protection and the allocation of responsibility in: C-145/83 Adams v Commission, ECLI:EU:C:1985:448, para. 34. 
such practice is against the principle of reliable and transparent administration (Bauer and Trondal, 2015, p. 10), where the evaluation of procedural rights and guarantees is also uncertain. ${ }^{36}$ It also reveals the question of direct effect from the perspective of EU citizens since their other procedural rights, embodied in the Charter of Fundamental Rights of the European Union (EU Charter) ${ }^{37}$ including the right to good administration, ${ }^{38}$ in general also become an open question (Csatlós, 2016, pp. 47-48).

The emergence of composite procedures with forms of vertical and horizontal administrative cooperation gives, therefore, rise to legal problems. It involves especially the protection of individual rights and supervision of administrative actions, including the allocation of responsibility of the actors and the application of law for those phases of the procedure which are transnational. Difficulties in allocating responsibility leads to problems in finding adequate remedies for maladministration within the network (Hofmann, 2009a, pp. 210-212, 220; Hofmann, 2015, p. 305). The importance the latter in a multiple-step procedure was also highlighted by the Tillack case (Hofmann, 2009a, p. 201). ${ }^{39}$ However, even legal remedy issues are traced

36 The European Administrative Space is built upon common constitutional principles rooted in democratic traditions of EU Member States. Particularly important principles set forth in the jurisprudence of the European Court of Justice, which all Member States must apply domestically when applying EU law, include: the principle of administration through law; the principles of proportionality, legal certainty, protection of legitimate expectations, non-discrimination, the right to a hearing in administrative decision-making procedures, interim relief, fair conditions for access of individuals to administrative courts, non-contractual liability of public administration. Basically, the main administrative law principles which are set as standard are: reliability and predictability (legal certainty); openness and transparency; accountability; and efficiency and effectiveness; SIGMA 27, p. 8.

37 Charter of Fundamental Rights of the European Union, OJ C 326, 26.10.2012, pp. 391-407 (hereinafter, EU Charter).

38 EU Charter, Article 41: 1. Every person has the right to have his or her affairs handled impartially, fairly and within a reasonable time by the institutions and bodies of the Union.

2. This right includes:

- the right of every person to be heard, before any individual measure which would affect him or her adversely is taken;

- the right of every person to have access to his or her file, while respecting the legitimate interests of confidentiality and of professional and business secrecy;

- the obligation of the administration to give reasons for its decisions.

3. Every person has the right to have the Community make good any damage caused by its institutions or by its servants in the performance of their duties, in accordance with the general principles common to the laws of the Member States.

4. Every person may write to the institutions of the Union in one of the languages of the Treaties and must have an answer in the same language.

39 Order of the President of the Court of First Instance T-193/04 Tillack v Commission [2004] ECR 11-3575, 53; Order of the President of the Court in C-521/04 P(R) Tillack v Commission [2005] ECR 1-3103, 46. 
back to the regulatory deficiencies on the construction and functioning of multi-level governance networks. As such, non-conformity with organisational principles of accountability and transparency (Hofmann, 2009a, 225) may lead to a threat to fundamental rights protection.

Even if an adequate ad hoc solution might serve effectiveness, it might not serve legitimacy and legality. The major dilemma is whether to put aside democratic notions, and rely on managerial concerns like efficiency and control, and accept and conclude that problem-solving capacity shall take precedence over democratic input. ${ }^{40}$

Given the fact that the rule of law is set out to be one of the major values of the EU, ${ }^{41}$ its requirement shall not be ignored. As a solution, Metcalf pointed out the nature of coordination and the need for a different approach to it in case of networks. He would step over the classical strict administrative control to the exercise of directed influence as generally, networks in EU law lack the hierarchical, central top-down steering. Instead of a monocentric model of coordination, he puts emphasis on a legal framework that will enable external judicial review to networks 'to respond to errors and deviations that arise from network management' (Metcalf, 2001, p. 7). This point of view was supported by academics who carried out extensive work on the codification of public administrative procedural rules of the EU. Networks involve information exchange between distinct public authorities from various jurisdictions. Therefore, ' $[\mathrm{u}]$ nder such circumstances a clear and stable legal basis for the interaction between those authorities provides not only for a clear allocation of responsibilities but also for administrative effectiveness and efficiency'. ${ }^{42}$

It is clear from the case-law of the CJEU that the duty of Member States, under the principle of sincere cooperation, to take all appropriate measures, whether general or particular, to ensure fulfilment of the obligations arising from EU law and to abstain from any measure which could jeopardise the attainment of the objectives of the Treaty. ${ }^{43}$ The obligation of sincere cooperation (Klamert, 2014, p. 141; Amerasinghe, 2005, pp. 176-187) ${ }^{44}$ and respecting the principle of the rule of law (Marsden, 2009, p. 24; Raitio, 2003, pp. 125-146) along with equality, which delimits the Commission's discretion as it is 'required to treat persons and undertakings equally if they

40 The problem is the same as in the case of multi-level governance (MLG) as, in fact, regulatory networks are a sort of MLG. See the dilemma in case of MLG: Peters and Pierre, 2004, p. 85; Bache and Flinders, 2004, p. 202.

41 TEU preamble; Article 2.

42 ReNEUAL Book VI-3 (Galetta, Hofmann, Lottini, Marsch, Schneider and Tidghi, 2014, pp. 270-271).

43 C-344/98, Masterfoods Ltd v HB Ice Cream Ltd, ECLI:EU:C:2000:689, para. 49; C-2/97 Società italiana petroli SpA (IP) v Borsana Srl, ECLI:EU:C:1998:613, para. 26, 49.

44 TEU Article 4(3). Cf. Article 3. 
are in the same situation' (Voss, 2013, p. 156-157), may positively influence the interpretation of different kinds of rules, but it is not enough to deduce concrete obligations and it cannot substitute hard law from the point of view of legal certainty (Galetta, Hofmann, Lottini, Marsch, Schneider and Tidghi, 2014, p. 239 para. 11) in composite procedures that involve a supra-national body or authority with a coordinating role and/or empowerment that makes it different in competences than all of the 28 actors. As Jimenez concludes, '[1] egal certainty is thus, the basis for an effective internal market and thus, economic efficiency' (Jimenez, 2016, p. 192) and the road towards this lies, among others, in a comprehensive procedural framework.

\section{The European Competition Network in view of legal challenges concerning networks}

Regulation 1/2003 was adopted by the Council and EU law is exclusively interpreted by the CJEU. ${ }^{45}$ However, according to classical international law on the interpretation of treaty provisions, the issuer is the authentic source of interpreting the norms (Linderfalk, 2007, p. 54-56). ${ }^{46}$ All the recommendations of the ECN start with the expression 'the ECN Competition Authorities (the Authorities) express common views', and ends with a disclaimer that stresses its non-binding nature, the fact that it does not give rise to legitimate expectations on the part of any undertaking or third party, and that it does not reflect any official or binding interpretation of procedural rules or the practice of any authority. ${ }^{47}$ Meanwhile, such soft law documents, meant to achieve a uniform execution of EU competition policy, are relevant to detect substantive law and the CJEU also acknowledged the practice that under certain circumstances they can give rise to legitimate expectations (Ştefan, 2013, pp. 197-200).

Harmonisation of substantive rules by such instruments goes only half way towards the proper and uniform application of EU competition law. The other half would be the procedural aspect of the sphere, which is the genesis of the meeting of direct and indirect administration. Regulation 1/2003 declares that it respects the fundamental rights and observes the principles recognised in particular by the EU Charter, thus all the provisions should be interpreted

45 Article 267(a) TFEU.

46 Vienna Convention on the Law of Treaties, Vienna, 23 May 1969, 1155 UNTS 331 (hereinafter, VCLT), Article 31.

47 See: Documents: Investigative and decision-making powers. http://ec.europa.eu/ competition/ecn/documents.html (10.03.2018). 
and applied with respect to those rights and principles. ${ }^{48}$ Although, again, principles cannot create competences or substitute for exact procedural guarantees, they are just interpreting existing competences and guarantees in the right way. The lack of procedural details, that serves as guarantees against the tyranny of public administration (that is, the competition authority or authorities taking part in any part of the procedure), may have consequences for individuals (Ştefan, 2013, p. 182).

Soft law measures mostly determine procedures of the ECN, apart from certain specific rules and safeguards of information exchange set forth in Regulation 1/2003. Basically, therefore, the ECN's procedures on the work allocation regime fall beyond the reach of judicial control. The allocation of cases and the cooperation of authorities to that end in a single case are crucial for the undertaking concerned from the point of view of their rights covered by the concept of the right to good administration. Without binding selection criteria and considering the unpublicized nature of case allocation decisions taken within the ECN, it is difficult, if not impossible, to predict which authority will ultimately handle a particular case. This has important consequences for the undertakings concerned in terms of applicable procedural rights, including the right to access to documents. It also concerns substantive law and legal practice including the amount of penalties, which, for example, may be different due to the soft law nature of joint interpretative decisions. Therefore, the lack of predictability does not conform to the requirements of legal certainty (Brammer, 2008, p. 352). Extensive reliance on soft law measures alienates judicial power from the network and, consequently, results in the marginalisation of judicial control over the decisions taken within the network as a safeguard of the rights of parties under investigation as well as third parties. Likewise, it also eliminates the possibility of courts serving as a resolution forum (Cengiz, 2010, p. 673). Relying on the argumentation of Kovács, Tóth and Forgács, vertical indirect effect would let individuals rely on soft law provisions that limit the central coordinating authority, that is, the EU Commission's discretionary powers, but this would not have relevance in private (horizontal) disputes (Kovács, Tóth and Forgács, 2017, pp. 5-6). There is even evidence that in certain cases the particular wording of soft law instruments could create some expectations on the side of undertakings (Senden, 2004, p. 421; Ştefan, 2013, pp. 166-167, 177-179). Basically, however, the Commission has discretion to depart from the guidelines it imposed upon itself, although it shall remain within the frames of the requirements of equal treatment and the protection of legitimate expectations. Therefore, the 'legal effects of soft law are not linked, as in the case of hard law, to the

48 Regulation 1/2003, (37). 
intrinsic quality of the instrument to generate rights and obligations' (Ştefan, 2013, pp. 183-184; Voss, 2013, pp. 155-156). Instead, it is given full effect through the prism of legal principles and provision deeply rooted in Treaty provisions, that is, in hard law. The CJEU has not recognized binding legal effects of lawful soft law on individuals; however, the Court admitted binding legal effects of such instruments for the enacting institution (Ştefan, 2013, pp. 197-199).

The rule of law is a major value of integration as it is the first and outmost requirement for European administration. ${ }^{49}$ As a corollary to the rule of law, the principle of legality requires that actions remain under and within the law, ${ }^{50}$ and the principle of legal certainty requires EU legal rules to be clear and precise enough to ensure that legal relationships governed by EU law are foreseeable (Galetta, Hofmann, Puigpelat and Ziller, 2015, (8)-(9), p. 17). It means that individuals must be able to ascertain unequivocally what their rights and obligations are, and to be able to take steps accordingly, be it concerning substantive or procedural aspects of a situation. Despite the recommendations, a substantial level of convergence in the application of the rules has been achieved, but divergences subsist. According to examinations, it is due to differences in the institutional position of the individual NCAs and in national procedures and sanctions. ${ }^{51}$

\section{Future path of development}

Substantial law on the work of the ECN cannot ensure guarantees of the preliminary procedure that takes place within an information management network enclosing the features of enforcement and regulatory networks; ad hoc solutions based on some soft law provisions cannot substitute for legal acts and instruments that establish procedural rights for individuals (undertakings) in an administrative procedure performed within the ECN. ${ }^{52}$ Harmonisation in the form of a directive only addressed to Member States would not compensate for the lack of exact allocation of roles and responsibilities among all the participating authorities: the NCAs and the Commission in a transparent and predictable way.

49 Article 2 TEU.

50 See EU Charter, Article 52(1): Any limitation on the exercise of the rights and freedoms recognized by this Charter must be provided for by law and respect the essence of those rights and freedoms.

51 Network Notice, point 24, 31-32.

52 EP Soft Law Resolution, AA.2. 
According to the requirements of the rule of law, and general codification conclusions of legal literature, a basic act shall be adopted before an information-management activity may be performed: it may take the form of a regulation, directive, decision, or any other instrument which has binding legal effect. ${ }^{53}$ According to the academic point of view, this basic act must not necessarily be a legislative act. ${ }^{54}$ Consequently, soft law may also fulfil this function, as it is clear from practice that it is getting accepted as an important source of law. At the same time, the existing soft law does not fill the gaps of insufficient regulation of all the procedural phases of networking, that is, the legal frames of its functioning. 55

Since the entry into force of the Lisbon Treaty, a new competence is also available as a solution. The European Parliament and the Council, acting by means of regulations in accordance with the ordinary legislative procedure, may establish the necessary measures to regulate administrative cooperation to serve effective implementation. This competence is a supportive competence and the harmonisation of the laws and regulations of the Member States is excluded. This provision was a milestone in the history of administrative cooperation as it is the first provision empowering the EU legislators to legislate on administration, apart from the direct level. A legal act based on Article 197 TFEU, as a matter of fact, offers a solution. However, it shall be without prejudice (a) to the obligations of the Member States to implement Union law or to the prerogatives and duties of the Commission and it shall also be without prejudice (b) to other provisions of the Treaties providing for administrative cooperation among the Member States and between them and the Union. ${ }^{56}$ This latter provision may challenge the efficacy of the legal act on information management networking if the Commission's activity is determined and explained by soft law measures that can be disregarded by the Commission itself. Therefore, in the case of the ECN, where not only the NCAs act within the authority power but the Commission is also entitled to do so, the legal background to regulate the cooperation and the information management activity of both shall be regulated by a basic act of binding effect to fulfil the basic requirements of European administrative procedures.

53 ReNEUAL Book VI-3, (1)-(2) (Galetta, Hofmann, Lottini, Marsch, Schneider and Tidghi, 2014, p. 245).

${ }^{54}$ ReNEUAL Book VI-3, (15) (Galetta, Hofmann, Lottini, Marsch, Schneider and Tidghi, 2014, p 271).

55 ReNEUAL Book VI-3 (3) (15) (Galetta, Hofmann, Lottini, Marsch, Schneider and Tidghi, 2014, p. 245).

56 Article 197 TFEU. 


\section{Concluding remarks}

Direct enforcement of EU law has been traditionally kept at the national level. However, in recent years, the EU's competences in direct enforcement have expanded and its competition policy is a significant example for enforcement networks and 'hard, soft and case law-based enforcement standards' (Scholten, 2017, p. 1351). In trans-national networks interactions between inter-dependent actors extend well beyond national borders, and thus their own procedural regimes with all its guarantees. It should also not be forgotten that coordination represents a genuine contradiction and sets limits to the autonomy and the responsibilities of the different actors concerned (Senn, 2011, pp. 31-32). Therefore, due to the rule of law, the procedural guarantee system of this intermediate phase of the composite administrative procedure shall be clearly and transparently regulated.

The ECN is a rather successful form of cooperation despite the fact that its core issues fail to correspond to the fundamental requirements of European administrative procedures; having said that, positive changes seem to take place in the evaluation of soft law and the functioning of the system. In one way, it is a model for all the cooperation networks of authorities, as it embodies legal questions and challenges as all the networks do; the development path that the ECN has experienced serves as a lesson. On the other hand, its specificities make it unique and even if its current regulation tries to correspond to it, a basic act encompassing and clarifying the administrative procedure of its cooperation would better serve people's Europe and the requirements of the EU vis-à-vis its own public administration.

\section{Literature}

Amerasinghe, C.F. (2005). Principles of the Institutional Law of International Organizations. Cambridge: Cambridge University Press.

Peters, B.G. and Pierre, J. (2004). Multi-level Governance and Democracy: A Faustian Bargain? In I. Bache and M. Flinders (eds), Multi-level Governance. Oxford: Oxford University Press, 75-89.

Bache, I. and Flinders, M. (2004). Multi-level Governance: Conclusions and Implications. In I. Bache and M. Flinders (eds), Multi-level Governance. Oxford: Oxford University Press, 195-206.

Bauer, M.W. and Trondal, J. (2015). The Administrative System of the European Union. In M.B. Bauer and J. Trondal (eds), The Palgrave Handbook of the European Administrative System. Basingstoke: Palgrave Macmillan, 1-28. 
Bianchi, A. (2016). International Law Theories: An Inquiry into Different Ways of Thinking. Oxford: Oxford University Press.

von Bogdandy, A., Dann, P. and Goldmann, M. (2010). The Exercise of Public Authority Advancing International Institutional Law by International Institutions. Berlin-Heidelberg: Springer Verlag.

Brammer, S. (2008) Horizontal aspects of the decentralisation of EU competition law enforcement. Doctoral dissertation. Katholieke Universiteit Leuven. Retrieved from: https://irias.kuleuven.be/bitstream/1979/1881/2/doctoraatbrammer.pdf (10.03.2018).

Cengiz, F. (2010). Multi-level governance in competition policy: The European Competition Network. European Law Review, 35(5), 660-677.

Chiti, E. (2011). EU and Global Administrative Organizations. Berlin Heidelberg: SpringerVerlag.

Chiti, E. (2015). In the Aftermath of the Crisis - The EU Administrative System Between Impediments and Momentum. Cambridge Yearbook of European Legal Studies, 17(1), 311-333.

Csatlós, E. (2016). Perspectives of the Cooperation of National Administrative Authorities in the EU. Jogelméleti Szemle, 16(3), 45-55.

Curtin, D. and Egeberg, M. (2013). Towards a New Executive Order in Europe? London: Routledge.

Dezső, M. and Vincze, A. (2012). Magyar alkotmányosság az európai integrációban. Budapest: HvgOrac.

Drechsler, W. (2009). Towards a Neo-Weberian European Union? Lisbon Agenda and Public Administration. Halduskultuur, 10, 6-21.

Fegus, V.R. (2014). The Growing Importance of Soft Law in the EU. InterEULawEast, $1(1), 145-161$.

Ficzere, L. (2011). Európai közigazgatás - nemzeti közigazgatás. In B. Gerencsér and P. Takács (eds), Ratio legis, ratio iuris: ünnepi tanulmányok Tamás András tiszteletére 70. születésnapja alkalmából. Budapest: Szent István Társulat, 383-384.

Galetta, D.U, Hofmann, H.C.H., Puigpelat, O.M. and Ziller, J. (2015). The General Principles of EU Administrative Procedural Law. Policy Department C: Citizens' Rights and Constitutional Affairs, Brussels: European Parliament. Retrieved from: http://www. europarl.europa.eu/RegData/etudes/IDAN/2015/519224/IPOL_IDA(2015)519224_ EN.pdf (10.03.2018).

Galetta, D.U., Hofmann, H.C.H., Schneider, J.P. and Tünsmeyer, V.M. (2014). ReNEUAL Model Rules on EU Administrative Procedure, Book V-Mutual assistance. Retrieved from: http://www.reneual.eu/images/Home/BookV-mutual_assistance_online_ publication_individualized_final_2014-09-03.pdf (10.03.2018).

Galetta, D.U., Hofmann, H.C.H., Lottini, M., Marsch, N., Schneider, J.P. and Tidghi, M. (2014). ReNEUAL Model Rules on EU Administrative Procedure, Book VI-Administrative Information Management. Retrieved from: http://www.reneual.eu/images/Home/ BookVI-information_management_online_publication_individualized_final_2014-0903.pdf (10.03.2018.)

Hardacre, A. and Kaeding, M. (2011). Delegated \& Implementing Acts. The New Comitology. EIPA Essential Guide. Maastricht: European Institute of Public Administration. Retrieved from: http://aei.pitt.edu/33497/1/20110912105558_EipascopeSpecialIssue_ Art5.pdf (10.03.2018). 
Heidbreder, E.G. (2009). Structuring the European Administrative Space: Channels of EU Penetrations and Mechanisms of National Chance. KFG Working Paper Series, 5.

Hofmann, H.C.H. (2009a). Composite Decisionmaking Procedures in EU Administrative Law. Administrative Law Review, 61, 199-222.

Hofmann, H.C.H. (2009b). Which Limits? Control of Powers in an Integrated Legal System. In C. Barnard and O. Odudu (eds), The Outer Limits of European Law. Oxford: Hart Publishing, 45-62.

Hofmann, H.C.H. (2015). The Court of Justice of the European Union and the European Administrative Space. In M.B. Bauer and J. Trondal (eds), The Palgrave Handbook of the European Administrative System. Basingstoke: Palgrave Macmillan, 301-311.

Hofmann, H.C.H. and Türk, A.H. (2006). Policy implementation. In H.C.H. Hofmann and A.H. Türk, EU Administrative Governance. Oxford: Oxford University Press, 74-125.

Israel, A., Lang, J.M. and Hübener, F. (2016). A Practitioner's View on the Role and Powers of National Competition Authorities Background to the ECN plus project. Brussels: European Union. P/A/ECON/2016-06, PE 578.972.

Jimenez, C.L. (2016). The Fining System in the Enforcement of EU Competition Law: A Time for Reassessment? Doctoral Thesis. University of Southampton, Faculty of Business, Southampton Law School. Retrieved from: https://eprints.soton.ac.uk/404886/ (10.03.2018).

Kingsbury, B., Krisch, N. and Stewart, R.B. (2005). The Emergence of Global Administrative Law. Law and Contemporary Problems, 68(3)-(4), 15-62.

Kingsbury, B., Kirsch, N., Stewart, R.B. and Wiener, J. (2005). Foreword: Global Governance as Administration - National and Transnational Approaches to Global Administrative Law. Law and Contemporary Problems, 68(3)-(4).

Klamert, M. (2014). The Principle of Loyalty in EU Law. Oxford: Oxford University Press.

Klucka, J. (2007). The General Trends of EU Administrative Law. The International Lawyer, 41(4), 1047-1054.

Koprić, I., Musa, A. and Novak, G.L. (2011). Good Administration as a Ticket to the European Administrative Space. Zbornik PFZ, 61(5), 1515-1560.

Kovács, A., Tóth, T. and Forgács, A. (2016). Effects of European Soft Law at National Administrative Courts. Loyola University Chicago International Law Review, 14(1), 1-30.

Kristjánsdóttir, M.V. (2013). Good Administration as a Fundamental Right. Icelandic Review of Politics and Administration, 9(1), 237-255.

Linderfalk, U. (2007). On the Interpretation of Treaties. The Modern International Law as Expressed in the 1969 Vienna Convention on the Law of Treaties. Dordrecht: Springer.

Marsden, P. (2009). Checks and balances: EU competition law and the rule of law. Competition Law International, 5(1), 24-28.

Mastenbroek, E. and Martinsen, D.S. (2018). Filling the gap in the European administrative space: the role of administrative networks in EU implementation and enforcement. Journal of European Public Policy, 25(3), 422-435.

Mataija, M. (2010). The European Competition Network and the Shaping of European Competition Policy. Croatian Yearbook of European Law and Policy, 6, 75-101.

Metcalfe, L. (2001). Law, Conservatism and Innovation: a Management Perspective. In A. George, P. Machado and J. Ziller (eds), Law and Public Management: Starting to Talk. EUI Working Paper LAW, 12. San Domenico: European University Institute, 5-10. 
Muheme, D., Neyrinck, N. and Petit, P. (2016). Procedural Rights in EU Antitrust Proceedings. In C. Cauffman and Q. Hao (eds), Procedural Rights in Competition Law in the EU and China. Berlin-Heidelberg: Springer, 129-160.

Ortino, M. (2017). EU External Competences and the Participation to the Basel Committee on Banking Supervision, European Business Law Review, 28(6), 911-936.

Panizza, R. (2015). EU Administrative Law. Policy Department C: Citizens' Rights and Constitutional Affairs. Brussels: European Parliament. Retrieved from: http://www. europarl.europa.eu/RegData/etudes/ATAG/2015/519207/IPOL_ATA(2015)519207_ EN.pdf (10.03.2018).

Raitio, J. (2003). The Principle of Legal Certainty in EC Law. Dordrecht: SpringerScience+Business Media, B.V.

Roben, V. (2008). The Enforcement Authority of International Institutions. German Law Journal, 9(11), 1965-1986.

Scholten, M. (2017). Mind the trend! Enforcement of EU law has been moving to 'Brussels'. Journal of European Public Policy, 24(9), 1348-1366.

Schwarze, J. (2011). European administrative law in the light of the Treaty of Lisbon: introductory remarks. Brussels: European Parliament, Directorate General for Internal Policies Policy Department C: Citizens' Rights and Constitutional Affairs. Brussels: European Parliament. Retrieved from: http:/www.europarl.europa.eu/RegData/etudes/ note/join/2011/432777/IPOL-JURI_NT(2011)432777_EN.pdf (10.03.2018).

Senden, L.A.J. (2005). Soft law and its implications for institutional balance in the EC. Utrecht Law Review, 1(2), 79-99.

Senn, M. (2011). Non-State Regulatory Regimes. Understanding Institutional Transformation. Berlin-Heidelberg: Springer Verlag.

Slaughter, A.M. (2003). Global Government Networks, Global Information Agencies, and Disaggregated Democracy. Michigan Journal of International Law, 24(4), 1041-1075.

Smyrnova, K. (2013). Rethinking EU Soft Law: New Dimensions in Competition Law. Law of Ukraine, 13(3), 125-132.

Ştefan, O. (2013). Soft Law in Court: Competition Law, State Aid, and the Court of Justice of the European Union. European Monographs Series Volume 81. Alphen aan den Rijn: Kluwer Law International.

Torma, A. (2011). Az Európai Közigazgatási Térségről - magyar szemmel. Miskolci Jogi Szemle, 6, 196-210.

Türk, A.H. (2012). Lawmaking after Lisbon. In A. Biondi, P. Eeckhout and S. Ripley (eds), EU Law after Lisbon. Oxford: Oxford University Press.

de Visser, M. (2009). Network-Based Governance in EC Law: The Example of EC Competition and EC Communications Law. Portland: Hart Publishing.

Vogiatzis, N. (2018). The European Ombudsman and Good Administration in the European Union. London: Palgrave Macmillan.

Voss, K. (2013). The Principle of Equality: A Limit to the Commission's Discretion in EU Competition Law Enforcement? Global Antitrust Review, (6), 149-166.

Zaring, D. (2005). Informal Procedure, Hard and Soft, in International Administration. Chicago Journal of International Law, 5(2), 547-603. 